\begin{tabular}{|c|c|}
\hline & Asian Social Work Journal (ASWJ) \\
\hline $\begin{array}{c}\text { ASIAN SOCIAL WORK } \\
\text { JOURAL } \\
\text { (ASW) }\end{array}$ & Volume 4, Issue 1, February 2019 \\
& e-ISSN : 0128-1577 \\
& Journal home page: \\
& www.msocialwork.com \\
\hline
\end{tabular}

\title{
Collaborative Strategy in Preventing the Vulnerability of Elderly Informal Workers
}

\author{
Endah Dwi Winarni ${ }^{1}$, Ella Nurlela ${ }^{1}$, Diana $S .^{1}$ \\ 1Bandung College of Social Welfare, Indonesia \\ Corrrespondence: Endah Dwi Winarni (endah_dwiwinarni@yahoo.id)
}

\begin{abstract}
The elderly who work in an informal sector tend to bear two layers of vulnerability: both body and mental functions that have been degenerated and the insecurities of the job. Status as an informal worker does have an impact on the uncertain income, also the absence of health benefits, pensions, or workers' compensation. Even if the state guarantees social protections for the elderly, it still has a formidable challenge when it must to be provided for the elderly informal workers specifically, for example, a contribution-based pension that reaches more to the elderly formal workers. Thus, this study discusses the efforts in preventing the vulnerability of elderly informal workers, especially the elderly farmers who are chosen as a case's subject in this study. Previous studies in a similar topic often emphasize the role of the state in preventing the vulnerability of elderly informal workers (a vertical scheme). In contrast to those studies, the argument of this study is the collaborative roles between the state and communities that are based on capability approach and social capital is able to prevent the vulnerability of elderly informal workers (vertical and horizontal synergy schemes). This study is written based on a case study research with the qualitative approach on the elderly farmers in Padamukti Village, Sukaresmi Subdistrict, Garut Regency, West Java, Indonesia.
\end{abstract}

Key words: elderly workers, informal sector, capability approach, social capital

\section{Introduction}

The elderly who have a status of worker in Indonesia, or it is called as "the potential elderly" based on Indonesian Law 13/1998 about the Elderly Welfare, are predominantly lived in rural areas and worked in an informal sector which is agriculture. In 2015, the elderly who worked in rural areas were $53.54 \%$ and in urban areas were $39.46 \%$; then, in 2016 , the elderly who worked in rural areas were $55.35 \%$ and in urban areas were $39.55 \%$; and in 2017 , the elderly who worked in rural areas were $55.34 \%$ and in urban areas were 40.93\% (Indonesian Central Bureau of Statistics, 2015; 2016; 2017). From these data, in the rural areas themselves, the majority of elderly is worked in agriculture. In 2017 , for example, $74.25 \%$ of the elderly workers in rural areas were worked in agriculture, then $10.70 \%$ in trade, $7.56 \%$ in industry, $3.63 \%$ in services, and 3.86\% in other fields (Indonesian Central Bureau of Statistics, 2017).

The high amount of elderly informal workers in Indonesia has its own challenges, namely two layers of vulnerability that are experienced. They do not only seem like a vulnerable person due to both body and mental functions that have been degenerated (Atchley, 1983), but also they bear the insecurities of the job. Status as an informal worker does have an impact on the uncertain income, also the absence of health benefits, pensions, or workers' compensation. United Nations (2012) states that the term 
informal sector is used because it does not have social security and, in particular, is more at risk of going bankrupt if market demand deteriorates.

Even if the state guarantees social protections for the elderly, this still has a formidable challenge when it must to be provided for the elderly informal workers specifically. For instance, the financial protection mechanism in form of a contribution-based pension that is still limited as a plan for the elderly informal workers, even though this has already been implemented for the elderly formal workers (Yulaswati, 2015). Moreover, in 2017, out of a total of $55.34 \%$ of the elderly workers in rural areas, $39.41 \%$ were classified as vulnerable workers - it means, more of those whose income was less than IDR 1,000,000 per month or tended to not meet standards (Indonesian Central Bureau of Statistics, 2017). Therefore, this study discusses the efforts in preventing the vulnerability of elderly informal workers, especially the elderly farmers who are chosen as a case's subject in this study.

The argument of this study is the collaborative roles between the state and communities that are based on capability approach and social capital is able to prevent the vulnerability of elderly informal workers (vertical and horizontal synergy schemes). This means that there is a synergy of vertical (from the state to communities) and horizontal schemes (from the communities themselves) in preventing the vulnerability situations of elderly informal workers. The definition of the capability approach is a development function that is not oriented to the material aspect, yet the empowerment (Sen, 1999). Meanwhile, the definition of social capital is a form of social networks (groups or communities) that is based on a trust to achieve common goals (Putnam, 1993). That argument is contrasted from the argument tendency of previous studies in a similar topic; which often only emphasize on the role of the state in preventing the vulnerability of elderly informal workers-limited to vertical scheme, such as a decentralized social security model to reach informal workers (see Mudiyono, 2002; Susilawati \& Nilakusmawati, 2015), an institutional innovation on social protection scheme (see Laiglesia, 2011), and inclusive policies on informal workers (see Malina, 2013).

\section{Methodology}

This study is written based on a case study research with the qualitative approach on the elderly farmers in Padamukti Village, Sukaresmi Subdistrict, Garut Regency, West Java. The qualitative approach is chosen because it can accommodate this study's purpose, namely to develop a strategy to prevent the vulnerability of elderly informal workers - this requires a naturalistic-interpretative approach to obtain the depth of data, through in-depth interviews, in an effort to detect existing problems thoroughly (see Creswell, 2003). As for both of the case's subject and location selection, in Garut Regency during 2014, 2015, and 2016, the amount of elderly had always increased. In 2014, the amount of elderly were 217,530 people; then in 2015, the amount were 227,642 people; and in 2016, the number reached 231,168 people (Garut Regency Central Bureau of Statistics, 2015; 2016; 2017). From these data, in 2016, there were 96,325 workers which the majority were worked in agriculture (Garut Regency Central Bureau of Statistics, 2016).

This study's data collection was conducted with in-depth and brief interviews, observation, documents exploration, and literature review; then, the collected data was processed with thematic technique and validated with the triangulation technique. In-depth interview was completed to nine people that are grouped into three, namely farmers, the communities of the farmer, and the local government. All of the interviews were undertaken with Indonesian, but all of the citations that are written in this study were translated literally into English by the authors. As for a brief interview was performed because the authors visited the case's location several times with a short duration. This study's data collection process had been conducted during the third quarter of 2018 .

\section{The Case's Location: Padamukti Village}


Padamukti Village, Sukaresmi Subdistrict, Garut Regency, West Java, Indonesia was originally established by the wishes of local people who want to get government services that are more effective and efficient. So, in 1983, a village expansion committee was formed, which at that time also immediately applied for an expansion to the local government. By passing through various expansion processes that are in accordance with the rules of law, for example, it is starting from determining the name of village, the division of villages area, the distribution of village wealth, etc., finally on November 5, 1983, Padamukti Village was established in the west of Garut Regency, in the north of Sukaresmi Subdistrict's capital city, and it is the result of Sukajadi Village (now Sukaresmi) expansion (Padamukti Village, 2017). The area of this village is 292,015 ha, consisting of 2 hamlets with 6 citizen associations (RW) and 33 neighborhood associations (RT) (Padamukti Village, 2017). The central area of this village is approximately $6 \mathrm{~km}$ from the central area of Sukaresmi Subdistrict, $20 \mathrm{~km}$ from the central area of Garut Regency, and $98 \mathrm{~km}$ from the central area of West Java (Padamukti Village, 2017).

Padamukti Village has adequate natural resources and it is ready to be processed. This can be seen from its location which is at a slope of $42 \%$ with an altitude above $850 \mathrm{~m}$ in an above sea level (Padamukti Village, 2017). So, this village is in the plateau and is very suitable for agricultural land. Furthermore, the land utilization in this village is divided into two parts, namely paddy fields and the mainland. Paddy fields are the largest land utilization in this village. Indeed, naturally, in the villages in Indonesia, the agricultural sector is the main foundation for local communities to fulfill their needs. The paddy fields in this village consist of technical fields area of 87,015 ha and rainfed fields area of 85,563 ha; while for mainland, there is a land area of 57 ha, community forest area of 10.890 ha, garden area of 51.522 ha, offices land area of 6 ha, and others area of 19 ha (Padamukti Village, 2017).

\section{The Synergy of Capability Approach and Social Capital}

Comim (2008) seeks to synergize the concept of capability approach and social capital for the sake of inclusive and empowering development schemes. According to Comim, the synergy is important due to the weaknesses of the two concepts. In brief, the definition of the capability approach is a development function that is not oriented to the material aspect, yet the empowerment (Sen, 1999). Meanwhile, the definition of social capital is a form of social networks (groups or communities) that is based on a trust to achieve common goals (Putnam, 1993). The weaknesses of both for Comim (2008) are: the capability approach tends to focus on a development function for the benefits of the individual, it does not see the potential of social networks that are also able to be utilized to increase the capacity to access or utilize resources; while social capital, the problem is that its function is doubtful as a form of investment for individuals, unlike other forms of capital, especially economic capital. So, if these two concepts are synergized, referring to Comim (2008), both of them interpret: a development function through the mechanism of social networks that is based on a trust in order to increase the capacity of individuals that are involved in it.

\section{Preventing the Vulnerability of Elderly Farmers}

\section{The Roles and the Obstacles of the State and Communities}

The Government of Padamukti Village has a role in preventing the vulnerabilities that are experienced by the elderly farmers. Some of these roles are part of programs that are integrated with the central and regional governments (a province and district). That is, in addition to the existence of independent programs from the village government, there are also programs that are carried out mainly by the central and regional governments (a province and district) — in this case, the village government role is a supporting staff for the implementation of the central and regional governments' programs.

However, the existing programs have not been specifically developed regarding the type of work that is owned by the elderly, such as the specific types of informal or formal work. This is more about 
programs that involve farmers in general or the elderly in general. If for farmers in general, the programs are carried out to support the productivity of these farmers, including those programs given to farmers who are elderly. Meanwhile, if for the elderly in general, the forms of programs are more in the form of social protection guarantees that are specifically given so that the elderly have a decent life in old age.

There are policies made for communities or groups of farmers. Actually, this already concerns farmers in general, including if the farmer is an elderly person (in-depth interview with Anita Rosita, Treasurer of the Government of Padamukti Village).

The role of the village government towards farmers in general, including the elderly farmers, there are three, namely material, non-material, and incidental. The material is technical assistance provided to support farmer productivity. In Padamukti Village, some technical assistance has been provided based on the results of discussions with farmers, such as irrigation facilities for irrigating paddy fields, distribution of pumps to suck up water, and assistance such as providing fertilizers, seeds, funds, and production aids for farmers. Then, non-material is non-technical assistance provided to support farmer productivity. For the government, this is important given as an effort to empower farmers so that they can independently and skillfully manage their land. Some examples of routine and non-routine programs are regular meetings every 3 months, advocating farmers not to suffer losses due to middlemen's threats, and developing capacity (training, counseling, or empowerment) to farmers organized by the agriculture department, irrigation office and BP3K. Lastly, incidental is assistance provided if there are unexpected situations that occur suddenly, such as natural disasters. For example, if there is a prolonged dry season, which has the potential to make crop yields difficult to flourish, the government will provide assistance so that it does not become a problem that disrupts agricultural productivity.

For this, the village government acknowledges that there are still a number of obstacles so that all goes well. Some of these obstacles are limited human resources and budget, making it difficult to provide programs specifically given to elderly farmers. In addition, the location or area of agriculture is also an obstacle. That is, the location or area of agriculture managed by elderly farmers is scattered and the distance is far away. As a result, the communication channels formed to preach each other's problems are often a challenge.

The obstacle so far is that our human resources, especially village government, is limited and there is no budget specifically for elderly farmers, especially the location or agricultural area managed by elderly farmers is scattered and the distance is far away (in-depth interview with Anita Rosita, Treasurer of the Government of Padamukti Village).

On the other hand, related to elderly social protection, the village government also has a role to provide guarantees to the elderly in general, not necessarily as farmers or whatever the profession. This is part of a central government program that does provide social security for the elderly. In this case, the role of the village government is only facilitating. There are several elderly social protection guarantee programs that are given, namely financial, non-financial, and active aging. For financial protection, there are pensions (retirement based contributions to formal workers and pensions based on social assistance) and old age savings. Then, for non-financial protection, there is health and care (based on social assistance). Finally, for the protection of active aging, there is empowerment and inclusiveness - that is to say, widening the access of the elderly to available public services.

In this case, the obstacle is that the funding coverage is often insufficient for the entire elderly in the village. Sometimes, there are some elderly people who are not satisfied with the guarantee or some who really do not get it. In addition, there is no guarantee of protection in the form of a contributionbased pension scheme for informal workers - for this, even from the central government is still limited as a plan for the elderly informal workers, even though this has already been implemented for the elderly formal workers (Yulaswati, 2015). 
The social protection is in accordance with the government, such as health and financial assistance in old age, etc. (in-depth interview with Anita Rosita, Treasurer of the Government of Padamukti Village).

If the protection issue is already in place, we only facilitate it from what the central government gives us. Especially for elderly farmers, this is not the way to do it, but generally, for farmers it has been conceptualized (in-depth interview with Anita Rosita, Treasurer of the Government of Padamukti Village).

As for the community, in this study, the groups studied were three groups of farmers. The three communities have their own characteristics. The three communities are the Mukti Tani Farmers Group, the Sugih Mukti Farmer Group, and the Tani Mawar Women Group. The first two groups are characteristically not too different, only the age is much different. Mukti Farmers are newly formed, in contrast to Sugih Mukti which has long been formed. Meanwhile, Mawar is part of a group of women farmers. The roles and obstacles of the three farmer groups are not much different so that they can be categorized into a common unity of aspects. The role of farmer groups on elderly farmers can be said to be generally divided into five aspects, namely technical assistance (sharing or borrowing and borrowing tools and materials), non-technical assistance (joint discussion or counseling), information assistance (sharing knowledge about agriculture or government assistance), personal assistance (mutual confiding, helping, and working together), and facilitating government programs (helping to succeed the agricultural program from the government). Then, the obstacles experienced in general are the amount and frequency of government assistance that is inadequate, less targeted, and inconsistent, communication with the government are stagnant, the model of empowerment from the government is not specific, and the independence of farmers in order to not always rely on the government.

The elderly farmers in this village are very enthusiastic. Very high while working even though it is elderly. In fact, they like to help young people who have not worked and become farmers in their fields. Sometimes, young farmers are still lazy to work in paddy fields. Now, this elderly farmer always gives advice, motivation, and enthusiasm to young people to continue working hard (in-depth interview with Cucun Rusmawan, Secretary of the Mukti Farmer Group).

Elderly farmers here have health complaints such as back pain or dizziness or tired sooner. But besides that, when they work, they are fine and excited. Yes, of course, there are complaints and obstacles. But here the point is that the farmer group, when it comes to complaints and agricultural barriers, can be solved together. We help each other or provide solutions to each other (in-depth interview with Asep Suryani, Member of the Sugih Mukti Farmer Group).

Elderly here is enthusiastic. If someone is sick, we also help each other by bringing them to the doctor or taking contributions (group interview with Anita Rosita, Ajeng, and Tini Tin Kartinah, Chairperson, Secretary, and Treasurer of the Tani Mawar Women's Group).

\section{The Elderly Farmers' Experience and Hope}

In general, there are two main reasons for the elderly in Padamukti Village to be associated with why they still work as farmers in their old age, namely paddy fields which are inherited (have been passed down through the family) and are still dependent. Although there is an acknowledgment that agriculture is informal and vulnerable workers, it is the most open opportunity given that it has become inherited. In fact, there were some informants who had worked in the city and/or other fields when they were young but had to go back to being farmers in their villages because the land under management was inherited. The old age does not prevent them from continuing to work as farmers because there are still dependents. This also makes the elderly farmers tend to want maximum roles from the community and government, namely for the sake of family welfare or overcoming the vulnerability of their profession as informal workers.

I work because I have dependents. Initially, this was rice fields from inherited land, some of them were bought for about 1 hectare. This field was worked on by other 
people, they worked with me (interview with OO Kadir Suhendar, a farmer in Padamukti Village).

Because there are still dependents and this land is also inherited land, it must be managed. The land is 500 tumbak, every day there are workers who manage it (interview with Dayat, a farmer in Padamukti Village).

I became a farmer because it had been passed down from a previous family who was also farmers. This field is inherited, there are approximately 400 tumbak. I still have dependents, family and children (interview with Ojon, a farmer in Padamukti Village).

As elderly farmers, there are advantages and disadvantages that they have even though they bear two vulnerabilities at once - physical matters and informal jobs that tend to be vulnerable. Some informants acknowledged that they could not afford to work full time for a week because of labor cases, so they needed to share time with employed workers. The problem is, income must be paid to workers because it is indeed an obligation. Regarding income, the informants acknowledged that the money earned was enough - just enough to suppress lifestyle. If viewed objectively, the informants admitted that their income was not satisfactory. The feeling of worry increases because there is no pension or savings for old age. For daily needs, one of the advantages of being a farmer is that if it is harvesting, a portion of the crop can be set aside for basic needs, not all sold.

Income is not fixed. Approximately, 4 months once a harvest can get IDR 2,400,000. That is the gross income. If the net income is at most IDR 2,000,000 because I have to pay workers (...) If asked so, yes, it is not enough. Even though I live in the village. But there are children who can help me with living expenses, they also already work. But this is, fortunately, working as a farmer, so if the harvest season arrives, the rice can be used for itself, some are just sold (...) there must be health problems because I am old. I have a blockage from my lungs to my heart because I smoke, I am also easily tired now-luckily there are workers in the fields so I work only to control them, and I fall asleep easily (interview with OO Kadir Suhendar, a farmer in Padamukti Village).

Regarding the various conditions of the informants as elderly farmers, they acknowledged that they were greatly helped by the existence of the community and the government. Especially the community, the informants tended to recognize the importance of the existence of the community. From the start of technical assistance, non-technical assistance, information assistance, and personal assistance provided by the community greatly helped the farmers. For example, not only about the assistance of tools or counseling, the informants acknowledged that fortunately there was a community that was sharing information, chatting with each other, familiarity, and helping each other not only in agriculture, but also medical matters or visit each other if someone is sick. Meanwhile, for the government, as the elderly, the informants said that the most felt benefit was the ease of treatment. According to the informant, thanks to government assistance, now medical treatment can be made easier and cheaper. In fact, medicines are free and easy to obtain.

Yes, there is agricultural counseling on how to plant and how to administer the correct fertilizer. Sometimes we were given fertilizer and seeds. It is uncertain, the price is sometimes free, but we have also paid for it even though it is not expensive. (...) I have a health card. (...) It is quite adequate, at least the health problem does not bother me (interview with Dayat, a farmer in Padamukti Village).

There are many benefits from the community, there are training, counseling, mutual assistance, sharing information about production and sales, and adding friends who are fellow elderly people so we can chat. (...) There is a card for health given by the government (interview with Ojon, a farmer in Padamukti Village). 
Even though the elderly farmers are quite satisfied with the health programs provided by the government, they still tend to complain about the available funds. They feel that these funds are often not enough to meet their needs and satisfy their worries in old age. Moreover, some informants explained that funding assistance was often not obtained, inconsistent. This is what makes the main hope of the elderly farmers regarding social security guarantees from the government, namely financial assistance that can meet the needs and satisfy the worry in old age.

My hope is to be given financial assistance for everyday life. It is because the income from agriculture is uncertain, if it is harvested it is good, but if it does not harvest, especially if there is bad weather, my life will be difficult (interview with OO Kadir Suhendar, a farmer in Padamukti Village).

Health assistance is enough, it is just that I do not get financial assistance. Financial assistance is important, especially in the village, the work is uncertain. (...) I hope to get financial assistance for daily expenses (interview with Ojon, a farmer in Padamukti Village).

\section{Collaborative Strategy between the State and Communities: Capability Approach and Social Capital}

In this section, the authors will present forms of collaborative strategies that can be done to overcome the problem of vulnerability of elderly farmers, which means that based on this context are elderly farmers in Padamukti Village, using the capability approach and social capital as a framework. In brief, the definition of the capability approach is a development function that is not oriented to the material aspect, yet the empowerment (Sen, 1999). Meanwhile, the definition of social capital is a form of social networks (groups or communities) that is based on a trust to achieve common goals (Putnam, 1993). So, if these two concepts are synergized, referring to Comim (2008), both of them interpret: a development function through the mechanism of social networks that is based on a trust in order to increase the capacity of individuals that are involved in it. Thus, in the context of these elderly informal workers, the capability approach and social capital are a basis for the existence of collaborative strategy between the state and communities (which the networks are formed based on a trust) to prevent the vulnerability situations of elderly informal workers (through the capacity building of them).

The authors have compiled strategies based on the dynamics of the roles of state and communities, the obstacles of state and communities, and the elderly farmers' experience and hope that have been explained in the previous two sections. These strategies are forms that can be pursued by the authority as a collaborative strategy to prevent the vulnerability of elderly farmers. The following is a detailed explanation of those strategies:

i. The state and communities should encourage and facilitate cross-age generations to cooperate with the private sector in making off-farm employment programs. This program can take the form of a company's CSR or a new business model. For example, wives or families of elderly farmers are empowered to make accessories or knick-knacks from processed land products for resale.

ii. The state and communities should encourage and facilitate cross-age generations to create programs that can expand market access for elderly farmers.

iii. The state must not only focus on providing funds, but together with the community should socialize the importance of financial planning for old age.

iv. The state supported by the communities must establish a pension scheme program for informal workers. The program can be in the form of setting aside the income of elderly farmers who are members of a joint business group in order to have savings in old age. The program can also be in the form of setting aside social assistance or subsidies or incentives in order to have savings in old age.

v. The state and communities should provide multiperspective and sustainable programs to farmers before entering old age, such as financial planning, independent garden management, 
utilization of information technology, regular joint sports programs, and environmental hygiene programs. This is important to do to fulfill long-term needs. If it is successfully implemented, this can foster independence to the recipient of the program when it enters old age.

vi. The state and communities should increase the frequency of routine meetings to discuss the latest conditions that are experienced by elderly farmers.

vii. The state and communities must exercise direct control or supervision. This is to overcome the challenges of access to technology that is difficult in the rural areas and for elderly farmers.

viii. The state must be able to provide the ease of administration for elderly farmers in obtaining benefits from existing programs, this should start from requirements, registration, to the contribution system obtained by elderly farmers. This is to overcome the challenges of decreasing physical, psychological, and cognitive conditions of the elderly.

\section{Conclusion}

Based on the analyzes described and the strategies prepared and offered, it can be reinforced the argument that the capability approach and social capital become relevant as a basis for the existence of collaborative strategy between the state and communities (which the networks are formed based on a trust) to prevent the vulnerability situations of elderly informal workers (through the capacity building of them). That is, in this strategy, there are two substances that are contained and important to see. First, the role of the state and communities in expanding access to various forms of social protection policies. Second, the role of the state and communities in increasing the people's capacity in order to utilize various forms of social protection policies. Furthermore, in an effort to develop Social Welfare disciplines, especially to focus on issues of elderly welfare, inclusive systems mechanisms and empowerment mechanisms are important to discuss further in order to make models of social development that are good for the welfare of the elderly in a country.

\section{References}

Atchley, C. R. (1983). Aging: Continue and Change. Belmont: Wadworth Publishing Co.

Indonesian Central Bureau of Statistics. (2014). Statistik Penduduk Lanjut Usia 2014. Jakarta: Badan Pusat Statistik.

Indonesian Central Bureau of Statistics. (2015). Statistik Penduduk Lanjut Usia 2015. Jakarta: Badan Pusat Statistik.

Indonesian Central Bureau of Statistics. (2016). Statistik Penduduk Lanjut Usia 2016. Jakarta: Badan Pusat Statistik.

Indonesian Central Bureau of Statistics. (2017). Statistik Penduduk Lanjut Usia 2017. Jakarta: Badan Pusat Statistik.

Garut Regency Central Bureau of Statistics. (2015). Garut dalam Angka 2015. Kabupaten Garut: Badan Pusat Statistik Kabupaten Garut.

Garut Regency Central Bureau of Statistics. (2016). Garut dalam Angka 2016. Kabupaten Garut: Badan Pusat Statistik Kabupaten Garut.

Garut Regency Central Bureau of Statistics. (2017). Garut dalam Angka 2017. Kabupaten Garut: Badan Pusat Statistik Kabupaten Garut.

Garut Regency Central Bureau of Statistics. (2017b). Kecamatan Sukaresmi dalam Angka 2017. Kabupaten Garut: Badan Pusat Statistik Kabupaten Garut.

Comim, F. (2008). Social Capital and Capability Approach. In J. W. Castiglione, The Handbook of Social Capital (pp. 624-651). New York: Oxford University Press.

Creswell, J. W. (2003). Research Design: Qualitative, Quantitative, and Mixed Methods Approaches (Second Edition). London: Sage Publications.

Padamukti Village. (2017). Profil Desa Padamukti, Kecamatan Sukaresmi, Kabupaten Garut, Provinsi Jawa Barat 2017. Garut: Desa Padamukti. 
Laiglesia, J. R. (2011). Coverage Gaps In Social Protection: What Role for Institutional Innovations. Paris: International Conference of Social Cohesion and Development.

Malina, R. (2013). Social Exclusion and the Plight of Aging in the Informal Sector in Tanzania: A Case of Arusha Region. Research on Humanities and Social Sciences, Vol. 3, No. 14, 54-59.

Mudiyono. (2002). Jaminan Sosial di Indonesia: Relevansi Pendekatan Informal. Jurnal Ilmu Sosial dan Ilmu Politik, Vol. 6, No. 1, 67-78.

Putnam, R. D. (1993). The Prosperous Community: Social Capital and Public Life. The American Prospect, Vol. 13, 35-42.

Sen, A. (1999). Development as Freedom. New York: Oxford University Press.

Susilawati, M., \& Nilakusmawati, D. P. (2015). Model Status Jaminan Sosial Lansia di Perkotaan Provinsi Bali. Denpansar: Seminar Nasional Sains dan Teknologi (Senastek).

United Nations. (2012, Februari 19). 1.7 Proportion of Own-account and Contributing Family Workers in Total Employment. Retrieved April 25, 2018, from Indicators for Monitoring the Millenium Development Goals (Definitons, Rationale, Concepts, and Sources): http://mdgs.un.org/unsd/mi/wiki/1-7-Proportion-of-own-account-and-contributing-familyworkers-in-total-employment.ashx

Yulaswati, V. (2015). Perlindungan Sosial Lanjut Usia. Jakarta: Kementrian PPN/Bappenas. 